\title{
Variability in the induction of alkaline phosphatase by histone deacetylase inhibitors in bladder and colon cancer cell lines
}

Michael A. Lea ${ }^{1, *}$, Elizabeth Batista1, Lauran Cue ${ }^{1}$ and Charles desBordes ${ }^{1,2}$

1 Department of Microbiology, Biochemistry and Molecular Genetics, Rutgers New Jersey Medical School, Newark, NJ, USA

${ }^{2}$ Department of Biology, Medgar Evers College - City University of New York, Brooklyn, NY, USA

\begin{abstract}
Induction of alkaline phosphatase activity has provided a convenient marker for differentiation of colon cancer cells. The degree to which different histone deacetylase inhibitors induce alkaline phosphatase and dipeptidyl peptidase activities was compared in bladder and colon cancer cell lines. The objective was to determine whether bladder cancer cell lines that retain activities of the cell surface hydrolases exhibit regulatory effects similar to those previously observed in colon cancer cells. Effects of histone deacetylase inhibitors on growth and alkaline phosphatase and dipeptidyl peptidase activities were studied in three human colon cancer cells and three bladder cancer cell lines. Growth inhibition was observed with all the histone deacetylase inhibitors that were examined. There was variability in the induction of enzyme activity with different histone deacetylase inhibitors but when induction was observed it was greater for alkaline phosphatase than for dipeptidyl peptidase. The data suggested that regulation of alkaline phosphatase and dipeptidyl peptidase activities by histone deacetylase inhibitors can be similar in bladder and colon cancer cells. However, the functional role of the enzyme activities in bladderderived cells remains to be established.
\end{abstract}

Keywords: alkaline phosphatase; histone deacetylase inhibitors; bladder cancer; colon cancer; growth

\section{Introduction}

Alkaline phosphatase and dipeptidyl peptidase are cell surface hydrolases that have been extensively studied as markers of differentiation in colon cancer cells [1-3]. In many colon cancer cell lines differentiation can be induced by prolonged incubation after confluence or by treatment with inhibitors of histone deacetylase (HDAC) activity $[4,5]$. Butyrate is a short-chain fatty acid that acts as a broad spectrum HDAC inhibitor. In some colon cancer cells, butyrate causes a several-fold induction of alkaline phosphatase but only modest effects on dipeptidyl peptidase $[4,5]$. A disadvantage of butyric acid as a potential therapeutic agent is its rapid metabolism. Another carboxylic acid with inhibitory action on a range of histone deacetylases is valproic acid [6]. Valproate has the advantage that it is already approved for some clinical applications. In addition to some carboxylic acids there are a variety of structures that are histone deacetylase inhibitors and these include some naturally occurring molecules $[7,8]$. One objective of the present work was to compare the action of different structural classes of histone deacetylase inhibitors as inducers of enzyme activity in bladder and colon cancer cells. In contrast to the situation in colon cancer, there is relatively little information on changes in cell surface hydrolase activity in bladder cancer. There is evidence for decreased alkaline phosphatase activity in bladder cancer [9-12]. Based on the studies of colon cancer, the hypothesis was investigated that there may be retention of activity of the alkaline phosphatase and dipeptidyl peptidase activities in more slowly growing bladder cancer cells and that the activity will be regulated by histone deacetylase inhibitors.

\section{Materials and methods}

Reagents

Histone deacetylase inhibitors were obtained from SigmaAldrich (St. Louis, MO, USA) except entinostat, romidepsin, and LMK235 that were purchased from Selleck Chemicals, (Houston, TX, USA) and belinostat which was obtained from Advanced ChemBlocks, (Burlingame, CA, USA).

*Corresponding author: Michael A. Lea, Department of Microbiology, Biochemistry and Molecular Genetics, Rutgers New Jersey Medical School, 225 Warren Street, Newark, New Jersey, 07103, USA. Tel.:+1 9739725345; Fax: +1 9739721286, Email: lea@njms.rutgers.edu

Received 29 December 2018 Revised 5 March 2019 Accepted 15 March 2019 Published 25 March 2019

Citation: Lea MA, Batista E, Cue L, desBordes C. Variability in the induction of alkaline phosphatase by histone deacetylase inhibitors in bladder and colon cancer cell lines. J Cancer Res Ther. 2019; 7(2):9-16. DOI: 10.14312/20524994.2019-2

Copyright: (c) 2019 Lea MA, et al. Published by NobleResearch Publishers. This is an open-access article distributed under the terms of the Creative Commons Attribution License, which permits unrestricted use, distribution and reproduction in any medium, provided the original author and source are credited. 


\section{Cells and determination of growth}

Human bladder cancer cell lines, namely 5637, HT1197, HT1376, RT4, T24, TCCSUP and UM-UC-3, and human colon cancer cells Caco-2, HT29 and SW1116 were obtained from the American Type Culture Collection (Rockville, MD, USA), and were incubated at $37^{\circ} \mathrm{C}$ with $5 \%$ carbon dioxide. After plating 5000 cells in 96 well plates in 0.2 ml RPMl-1640 with $5 \%$ fetal calf serum for $24 \mathrm{~h}$, medium was replaced with either control medium or medium containing HDAC inhibitors. After a further $72 \mathrm{~h}$ incubation cell growth was determined by the increase in protein using staining with sulforhodamine B essentially as described by Vichai and Kirtikara [13]. The medium was aspirated and the cells were incubated with $0.1 \mathrm{ml} 10 \%$ trichloracetic acid on ice for 60 min. After removing the $10 \%$ trachloroacetic acid, the fixed cells were washed twice with $0.3 \mathrm{ml}$ water and incubated with $0.1 \mathrm{ml} 0.057 \%$ sulforhodamine $B$ in $1 \%$ acetic acid for the $30 \mathrm{~min}$. Unbound dye was removed with two washes with $0.3 \mathrm{ml} 1 \%$ acetic acid and the bound dye was eluted with $0.2 \mathrm{ml} 10 \mathrm{mM}$ Tris solution ( $\mathrm{pH} 10.5)$. Absorbance of the bound dye was measured at $510 \mathrm{~nm}$.

\section{Enzyme assays}

In preliminary studies, enzyme assays were performed on cell extracts obtained with a non-ionic detergent as previously described $[4,5]$. In the present work, assays were performed directly on cells incubated in 96 well plates due to the localization of the enzyme on the plasma membrane. Medium was removed and the cells were incubated for $30 \mathrm{~min}$ at $37^{\circ} \mathrm{C}$ with $100 \mu$ l containing the substrate and buffer. Reagents were obtained from SigmaAldrich (St. Louis, MO, USA). For the alkaline phosphatase assays, the substrate and buffer were $5 \mathrm{mM}$ paranitrophenyl phosphate and $0.75 \mathrm{M}$ 2-amino-2-methyl1-propanol, $\mathrm{pH}$ 10.3. The incubation was stopped by the addition of $100 \mu \mathrm{l} 0.5 \mathrm{~N} \mathrm{NaOH}$. For the dipeptidyl peptidase assays, the substrate and buffer were $5 \mathrm{mM}$ glycyl-prolylpara-nitroanilide and $100 \mathrm{mM}$ Tris, $\mathrm{pH}$ 8.0. The incubation was stopped by the addition of $200 \mu \mathrm{l} 0.5 \mathrm{M}$ acetate buffer, $\mathrm{pH}$ 4.2. The formation of product was monitored by the absorption of light at $410 \mathrm{~nm}$ for alkaline phosphatase and $405 \mathrm{~nm}$ for dipeptidyl peptidase. Enzyme activities per unit protein were calculated by dividing the absorbance for the colorimetric enzyme assay by the light absorbance determined by staining with sulforhodamine B. A unit protein corresponded to that giving an absorbance of 1.0 at $510 \mathrm{~nm}$.

\section{Statistical evaluation}

Data are presented as mean \pm standard deviation for three or a greater number of determinations. Statistical significance of the results was determined by analysis of variance followed by Dunnett's test for multiple comparisons or by a two-tailed Student's $t$-test for comparison between two groups. A p-value less than 0.05 was considered statistically significant. Statistical analysis was performed using the InStat program from Graphpad Software, Inc.

\section{Results}

In our preliminary studies, seven human bladder cancer cell lines (5637, HT1197, HT1376, RT4, T24, TCCSUP and
UM-UC-3) were screened for alkaline phosphatase activity. Three cell lines with activity comparable to that in more differentiated colon cancer cell lines were identified. Subsequent work focused on the three bladder cancer cell lines, 5637, HT1197 and HT1376. The response to incubation with the HDAC inhibitors butyrate and valproate was compared with effects in three colon cancer cell lines Caco-2, HT29 and SW1116. In all six cell lines there were growth inhibitory effects that tended to be a little greater with butyrate than with valproate (Figure 1). Induction of alkaline phosphatase activity was generally greater with butyrate than with valproate (Figure 2). There were larger increases in the alkaline phosphatase activity per unit protein than for dipeptidyl peptidase activity per unit protein after treatment with butyrate or valproate (Figures 2 and 3 ).

Not all HDAC inhibitors induced expression of alkaline phosphatase. The data in Figure 4 compare the effects of 3 HDAC inhibitors, butyrate, LKM235, and tubacin, on cell growth and alkaline phosphatase activity per well for two bladder cancer cell lines 5637 and HT1197. At concentrations of the compounds that caused growth inhibition of similar magnitude, the induction of alkaline phosphatase activity was greater with butyrate than with LMK235 or tubacin.

The effects of pyruvate and lactate were studied because of data indicating that pyruvate could inhibit histone deacetylase activity under conditions where there was no inhibition with lactate [14]. Methyl pyruvate was examined as it was more membrane permeable than pyruvate and potentially effective at lower concentrations than pyruvate. The data in Figure 5 indicate that under conditions in which butyrate caused a large increase in activity of alkaline phosphatase per unit protein of HT1197 bladder cancer cells, there was no significant effect with an equal concentration of lactate or pyruvate. Only at a high concentration of methyl pyruvate was there a significant increase in alkaline phosphatase activity.

Normalization of enzyme activity on a protein basis can change the apparent influence of HDAC inhibitors on enzyme expression. A difficulty that we have encountered in comparing the effects of butyrate with more potent HDAC inhibitors, including belinostat, entinostat, LMK235, RGFP966, romidepsin and tubacin, is that the latter are more potent inhibitors of growth than butyrate. Thereby, there effects cannot be compared to the effects of butyrate at equal concentrations. This is illustrated by the data in Figure 6 comparing the actions of butyrate and romidepsin on HT1376 and 5637 bladder cancer cells. The results in Figure $6 a$ for HT1376 cells suggest that after incubation with butyrate there was a significant increase in alkaline phosphatase activity per well with 2 $\mathrm{mM}$ butyrate but significant decreases in activity with 2.5$10 \mathrm{nM}$ romidepsin. However, if the protein levels reflected by staining with sulforhodamine B in Figure $6 \mathrm{~b}$ are used to express the activity of alkaline phosphatase per unit protein, the data in Figure $6 \mathrm{c}$ indicate induction of alkaline phosphatase activity by both $2 \mathrm{mM}$ butyrate and by much lower concentrations of romidepsin. Inhibition of growth 

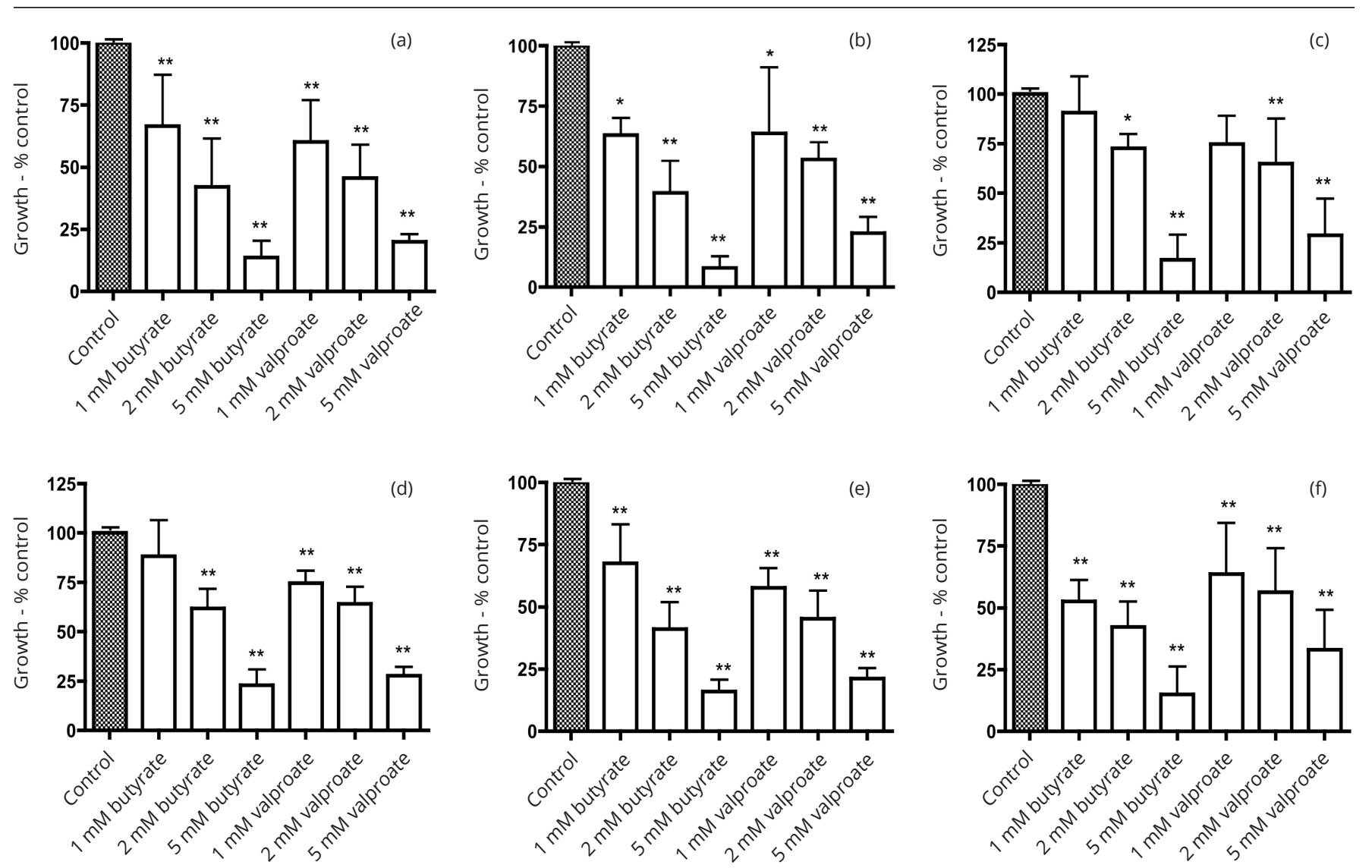

Figure 1 Effects of butyrate and valproate on the growth of cell lines as determined by sulforhodamine B assay after a 72 h incubation: (a) 5637 , (b) Caco-2, (c) HT1197, (d) HT1376, (e) HT29, (f) SW1116. Data are the means \pm SD of 3 or more determinations. Significantly different from control at $*$ p <0.05 and $* * \mathrm{p}<0.01$
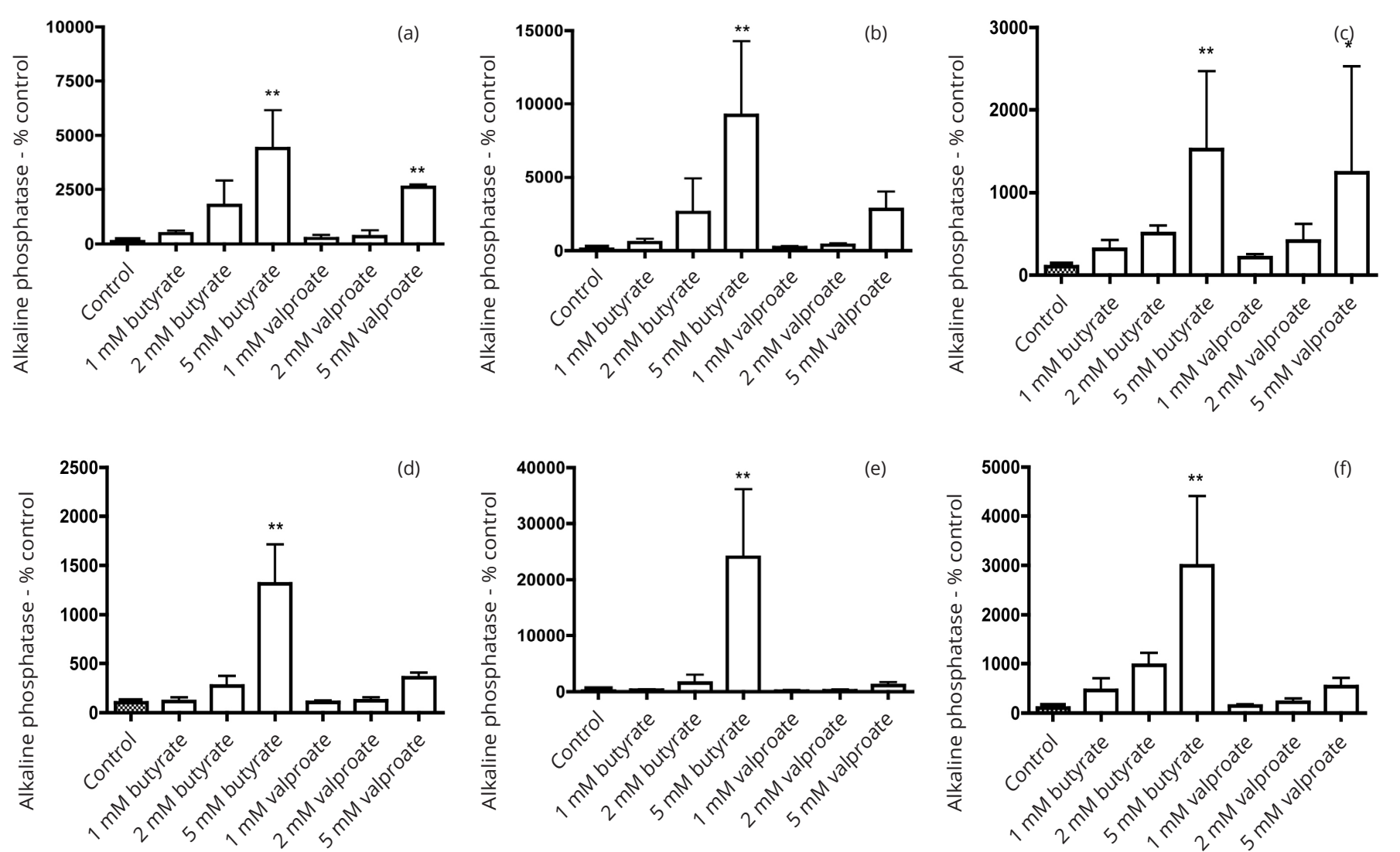

Figure 2 Effects of butyrate and valproate on the activity of alkaline phosphatase per unit protein expressed as a percent of control of cell lines after a $72 \mathrm{~h}$ incubation: (a) 5637, (b) Caco-2, (c) HT1197, (d) HT1376, (e) HT29, (f) SW1116. Data are the means \pm SD of 3 or more determinations. Significantly different from control at $* \mathrm{p}<0.05$ and $* * \mathrm{p}<0.01$. 

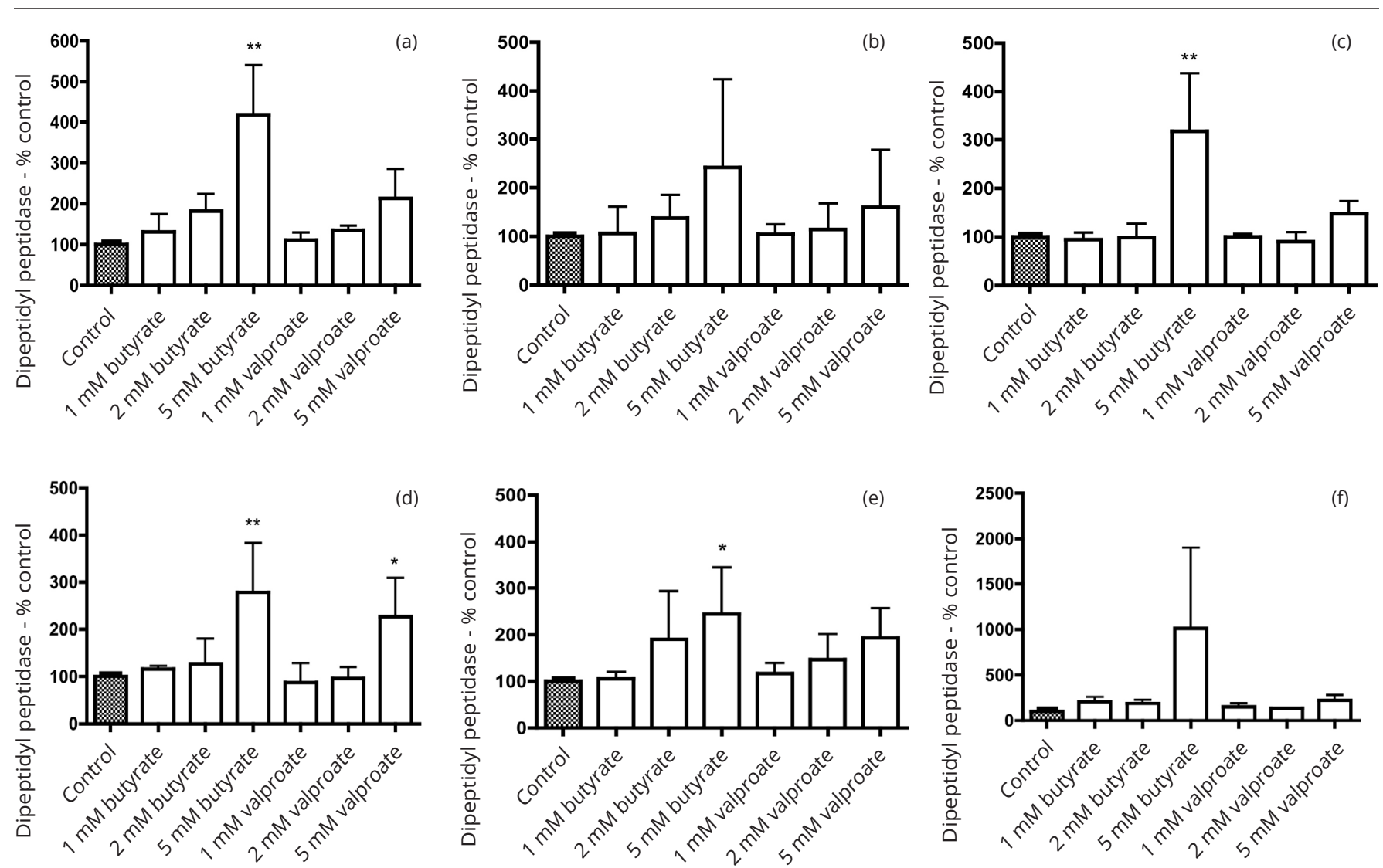

Figure 3 Effects of butyrate and valproate on the activity of dipeptidyl peptidase per unit protein expressed as a percent of control of cell lines after a $72 \mathrm{~h}$ incubation: (a) 5637, (b) Caco-2, (c) HT1197, (d) HT1376, (e) HT29, (f) SW1116. Data are the means $\pm S D$ of 3-6 determinations. Significantly different from control at $* \mathrm{p}<0.05$ and $* * \mathrm{p}<0.01$.
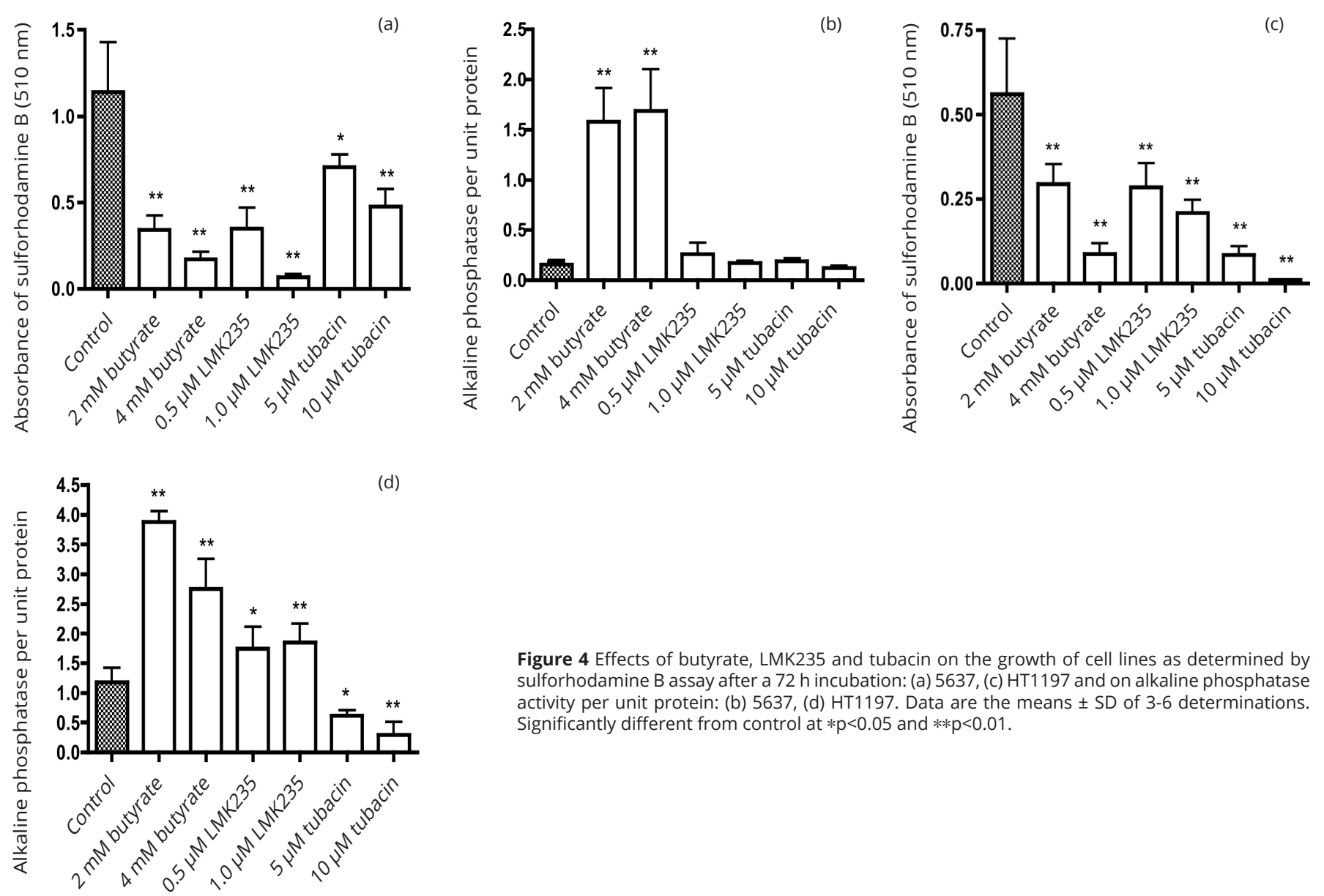

Figure 4 Effects of butyrate, LMK235 and tubacin on the growth of cell lines as determined by sulforhodamine B assay after a 72 h incubation: (a) 5637, (c) HT1197 and on alkaline phosphatase activity per unit protein: (b) 5637, (d) HT1197. Data are the means \pm SD of 3-6 determinations. Significantly different from control at $* \mathrm{p}<0.05$ and $* * \mathrm{p}<0.01$. 
by romidepsin was greater in HT1376 cells (Figure 6b) than in 5637 cells (Figure 6e) and, consequently, the difference in profiles between enzyme activity per well and per unit protein (Figures 6d \& f) was less for the 5637 cells.

The response of alkaline phosphatase expression can differ considerably between different cell lines and between the effects of individual histone deacetylase inhibitors. The data in Figure 7 show that, when expressed as activity per unit protein, the alkaline phosphatase activity in the bladder and colon cancer cell lines can be induced by entinostat to as great an extent as with butyrate. Results in Figure 8 illustrate the many-fold increase in alkaline phosphatase activity that can be induced by the histone deacetylase inhibitors RGFP966 and butyrate. Of the cells examined, the highest activity was observed with the HT1197 bladder cancer cell line.

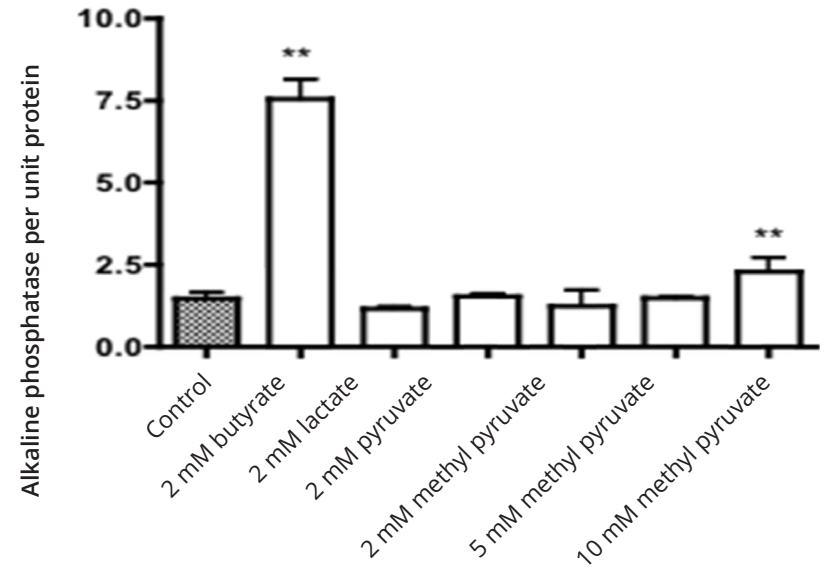

Figure 5 Activity of alkaline phosphatase activity per unit protein for HT1197 cells after a $72 \mathrm{~h}$ incubation with butyrate, lactate, pyruvate and methyl pyruvate. Data are the means \pm SD of 3-6 determinations. Significantly different from control at $* \mathrm{p}<0.05$ and $* * \mathrm{p}<0.01$.
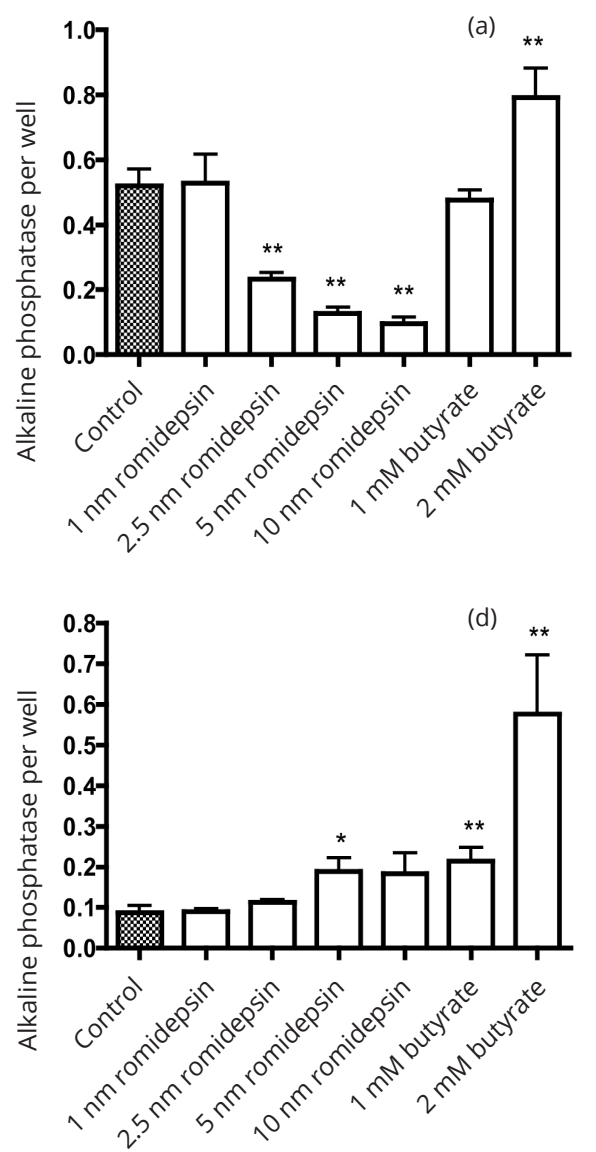
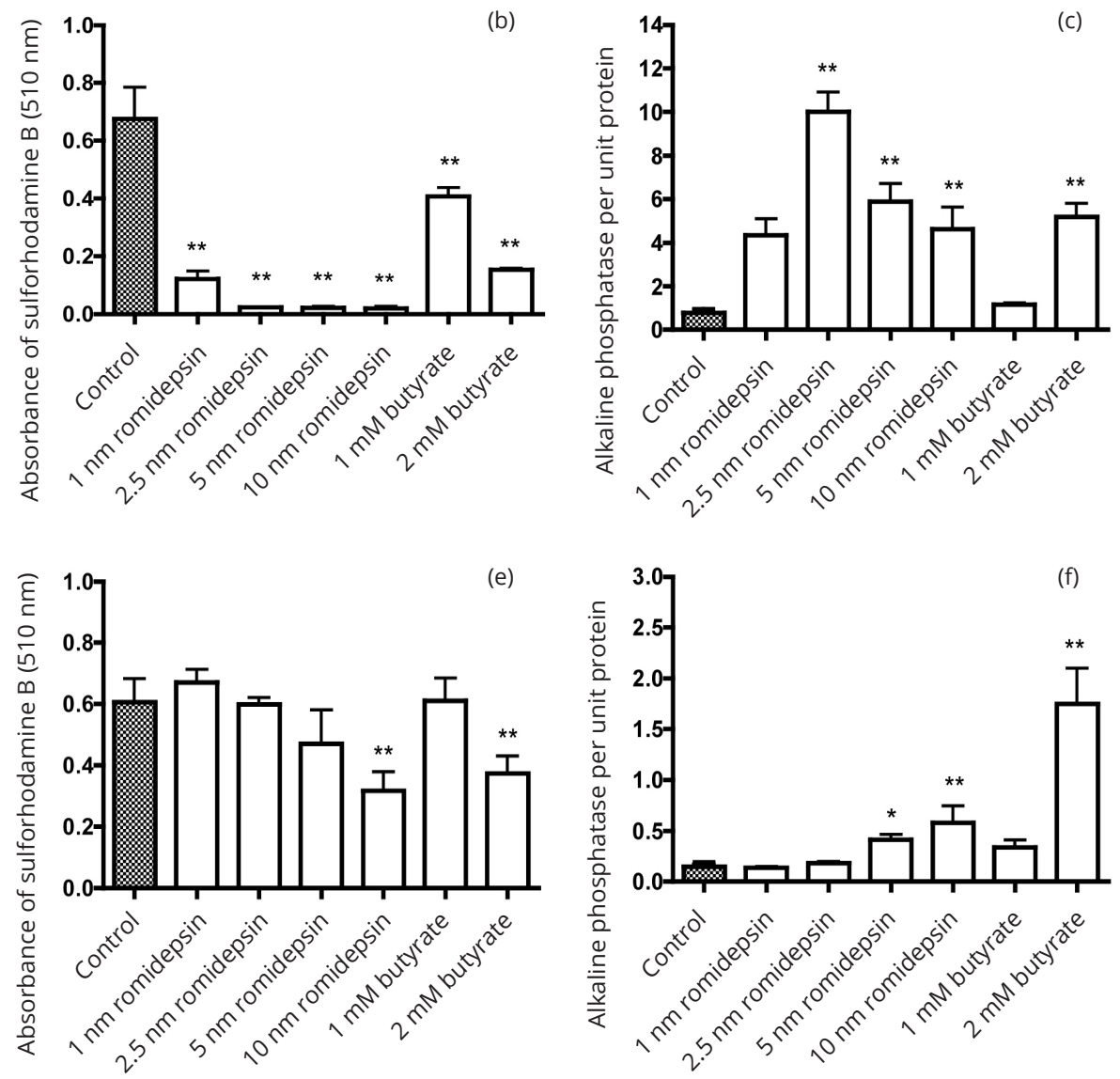

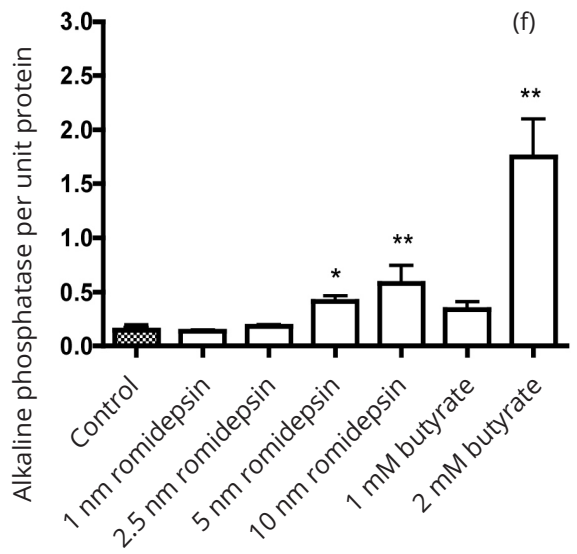

Figure 6 Effects of romidepsin and butyrate on HT1376 (a, b and c) and 5637 (d, e and f) cells after a 72 h incubation. Data are for alkaline phosphatase activity per well $(a, d)$, growth as represented by staining with sulforhodamine B (b, e) and activity of alkaline phosphatase per unit protein (c, f). Data are the means \pm SD of 3-6 determinations. Significantly different from control at $* p<0.05$ and $* * p<0.01$.

\section{Discussion}

Greater induction of alkaline phosphatase than dipeptidyl aminopeptidase activity by butyrate has previously been reported in the Caco-2, HT29, and SW116 colon cancer cell lines [15]. We have confirmed that observation (Figures 2 and 3) and found that it also holds for the three bladder cancer cell lines 5637, HT1197 and HT1376. Induction of alkaline phosphatase and dipeptidyl peptidase activities was greater with butyrate than with valproate in both bladder and colon cancer cell lines.
One of the disadvantages of studies using cultured cancer cells is the tendency for genetic drift and the loss of differentiated function. This has been noted in Caco-2 cells with a tendency for decreased alkaline phosphatase activity and a decreased induction by butyrate with prolonged passaging of the cells [16]. In our experience over a number of years, this decline can occur slowly and progressively, or abruptly. As with bladder cancer cells, we have seen the loss of induction of alkaline phosphatase activity by butyrate once with the 5637 cell line and twice with the HT1197 cells, necessitating a shift to stocks of frozen cells. 

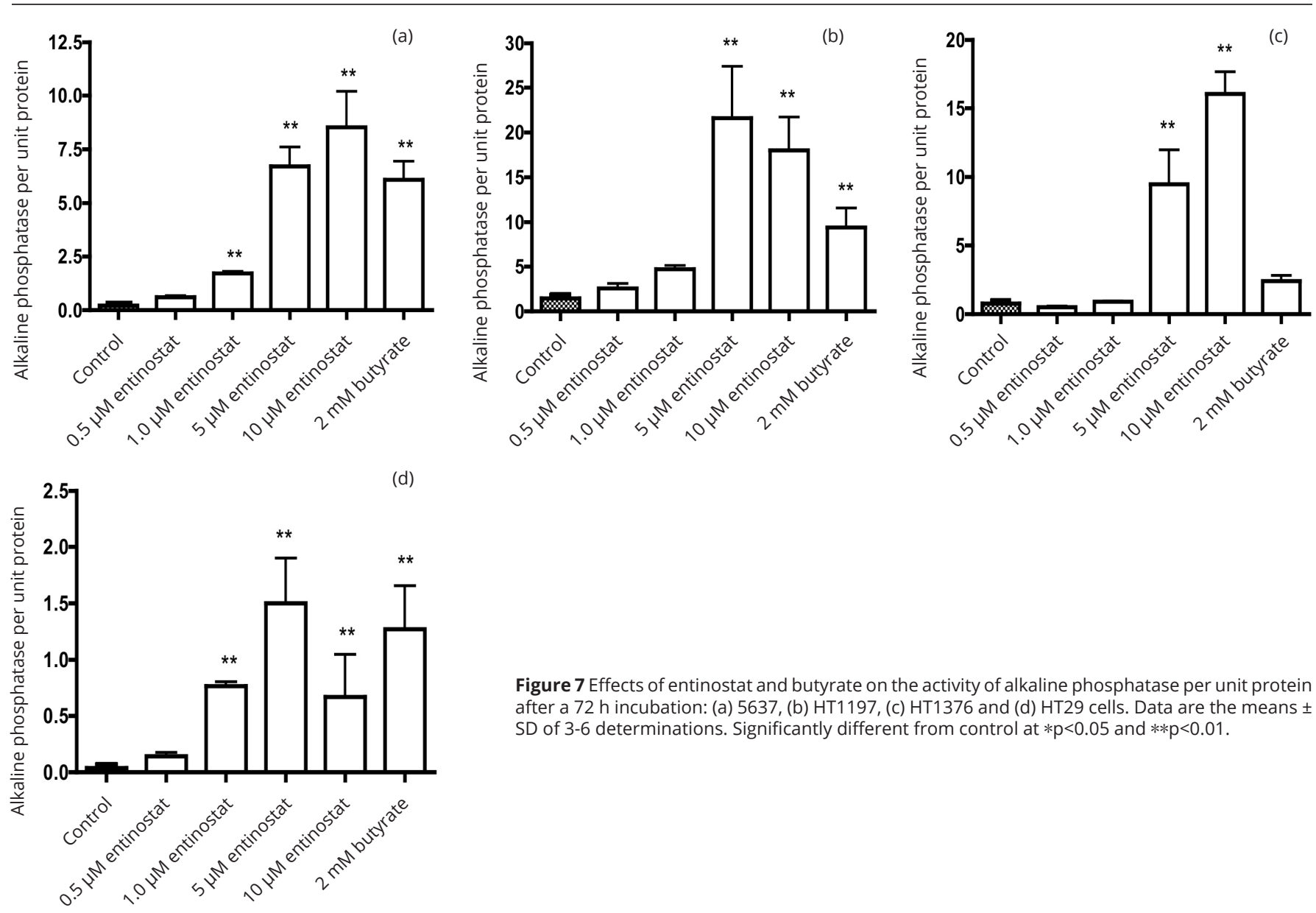

Figure 7 Effects of entinostat and butyrate on the activity of alkaline phosphatase per unit protein after a $72 \mathrm{~h}$ incubation: (a) 5637, (b) HT1197, (c) HT1376 and (d) HT29 cells. Data are the means \pm SD of 3-6 determinations. Significantly different from control at $* \mathrm{p}<0.05$ and $* * \mathrm{p}<0.01$.
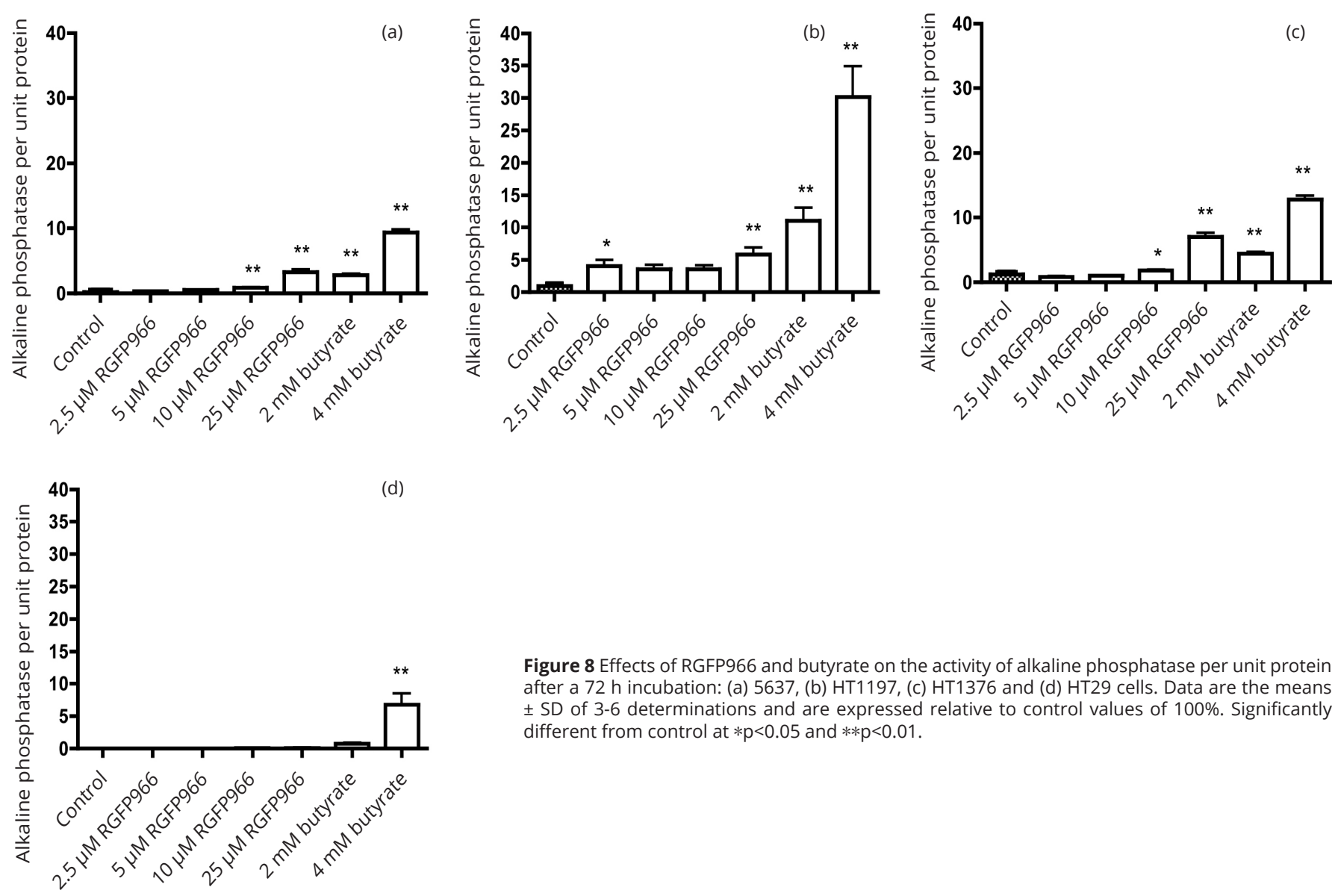

Figure 8 Effects of RGFP966 and butyrate on the activity of alkaline phosphatase per unit protein after a $72 \mathrm{~h}$ incubation: (a) 5637 (b) HT1197, (c) HT1376 and (d) HT29 cells. Data are the means \pm SD of 3-6 determinations and are expressed relative to control values of $100 \%$. Significantly different from control at $* \mathrm{p}<0.05$ and $* * \mathrm{p}<0.01$. 
Even when the cells failed to respond to HDAC inhibitors with an induction of alkaline phosphatase, there was continued sensitivity to growth inhibition. These observations suggest that growth inhibition need not be attributed to the same mechanisms that underlie enzyme induction. Colon cancer cell lines differ in their sensitivity to induction of alkaline phosphatase activity by butyrate [17]. In the case of bladder cancer cells, five of the cell lines that we examined (RT4, SW780, T24, TCCSUP and UM-UC-3) had little or no induction of alkaline phosphatase activity when treated with butyrate. For those cell lines where induction was observed (5637, HT1197 and HT1376), the levels were comparable to those seen with responsive colon cancer cells, but with individual degrees of response. The study of Highman et al. [18] indicated a progressive loss of alkaline phosphatase activity in bladders of carcinogen-treated mice and in transitional cell carcinomas there was no activity, except focally in a few tumors in 11 of 12 mice with tumors. It was suggested that loss of alkaline phosphatase in the bladder epithelium might be a preneoplastic change. Our data indicate that in some human bladder cancer cells there may be retention of alkaline phosphatase activity and responsiveness to induction by HDAC inhibitors.

A study with the JTC-32 human bladder carcinoma cells revealed less than a doubling of alkaline phosphatase activity with $1 \mathrm{mM}$ butyrate as a single agent but there was a synergistic effect with a combination of butyrate, dibutyryl cyclic AMP, prednisolone and sodium chloride [19]. The present data show that a several-fold increase in alkaline phosphatase can be seen with butyrate or other HDAC inhibitors as single agents in some human bladder cancer cell lines.

Several types of histone deacetylase inhibitors have been identified in colon cancer cells [20]. Butyrate, valproate, and hydroxamates are broad spectrum inhibitors affecting most histone deacetylases. Tubacin has specificity for HDAC6. The lack of effect of tubacin on induction of HDAC activity suggests that enzyme induction is not related to HDAC6 activity. HDAC3 is more sensitive to RGFP966 and HDAC4 and HDAC5 are more sensitive to inhibition by LMK235. Romidepsin is particularly active as an inhibitor of HDACs 1 and 2 and entinostat has shown some selectivity for HDAC1 and HDAC3. Induction of alkaline phosphatase activity was observed with these compounds, suggesting that inhibition of several HDACs may be related to enzyme induction. Induction can be observed with different types of molecules including hydroxamates, a peptide molecule and a benzamide derivative. Not all compounds reported as being HDAC inhibitors have been demonstrated to induce alkaline phosphatase activity in bladder and colon cancer cells. Examples include pyruvate and carnitine [14, 21 and unpublished date]. This was illustrated for pyruvate in Figure 5.

The function of alkaline phosphatases appears to vary in different tissues. The bone enzyme is thought to be involved in bone calcification and the intestinal activity may play a role in uptake of molecules [22]. A defined function does not appear to have been presented for alkaline phosphatase activity in the bladder. It has been suggested that alkaline phosphatase activity may control the availability of some signaling molecules and that inhibitors of alkaline phosphatase might modulate signaling activity [23]. At present, histone deacetylase inhibitors have primarily gained approval in the therapy of hematological malignancies. However, there is evidence for growth inhibitory effects on solid tumors, for example breast cancer cells [24]. The present data indicate that induction of alkaline phosphatase activity in bladder cancer cells can be accompanied by inhibition of growth. The therapeutic potential of epigenetic regulation in bladder cancer has been considered [25]. HDAC inhibitors may have a part to play in such therapeutic intervention against bladder and colon cancer.

\section{Conclusion}

This investigation identified three human bladder cancer cell lines, 5637, HT1376 and HT1197, that retain alkaline phosphatase activity that can be further induced by the action of histone deacetylase inhibitors, an action previously identified in colon cancer cells. Of the three cell lines, the highest activity has been observed in HT1197 cells. That cell line could be a suitable model for the characterization of the alkaline phosphatase activity in bladder cancer cells.

\section{Acknowledgements}

This work was supported in part by the Alma Toorock Memorial for Cancer Research. We are grateful to Erik Lew for technical assistance in a portion of this work.

\section{Conflict of interest}

Authors declare no conflict of interest.

\section{References}

[1] Kim YS, Tsao D, Siddiqui B, Whitehead JS, Arnstein P, et al. Effects of sodium butyrate and dimethylsulfoxide on biochemical properties of human colon cancer cells. Cancer. 1980; 45 (5 Suppl):1185-1192.

[2] Herz F, Schermer A, Halwer M, Bogart LH. Alkaline phosphatase in HT29, a human colon cancer cell line: influence of sodium butyrate and hyperosmolality. Arch Biochem Biophys. 1981; 210(2):581-591.

[3] Chung YS, Song IS, Erickson RH, Sleisenger MH, Kim YS. Effect of growth and sodium butyrate on brush border membrane-associated hydrolases in human colorectal cancer cell lines. Cancer Res. 1985; 45(7):2976-2982.

[4] Lea MA, Ibeh C, Shah N, Moyer MP. Induction of differentiation of colon cancer cells by combined inhibition of kinases and histone deacetylase. Anticancer Res. 2007; 27(2):741-748.

[5] Lea MA, Ibeh C, Han L, desBordes C. Inhibition of growth and induction of differentiation markers by polyphenolic molecules and histone deacetylase inhibitors in colon cancer cells. Anticancer Res. 2010; 30(2):311-318.

[6] Eckschlager T, Pich J, Stiborova M, Hrabeta J. Histone deacetylase inhibitors as anticancer drugs. Int J Mol Sci. 2017; 18(7):1414.

[7] Hanikoglu A, Hanikoglu F, Ozben T. Natural product inhibitors of histone deacetylases as new anticancer agents. Current Protein Peptide Sci. 2018; 19(3):333-340.

[8] Aztopal N, Erkisa M, Erturk E, Ulukaya E, Tokullugil AH, et al. Valproic acid, a histone deacetylase inhibitor, induces apoptosis in breast cancer stem cells. Chem-Biol Interact. 2018; 280:51-58.

[9] Herz F, Barlebo H, Koss LG. Modulation of alkaline phosphatase activity in cell cultures derived from human urinary bladder carcinoma. Cancer Res. 1974; 34(8):1943-1946.

[10] Highman B, Frith CH, Littlefield NA. Alkaline phosphatase activity in hyperplastic and neoplastic urinary bladder epithelium of mice fed 2-acetylaminofluorine. J Natl Cancer Inst. 1975; 54(1):257-261. 
[11] Benham F, Cottell DC, Franks LM, Wilson PD. Alkaline phosphatase activity in human bladder tumor cell lines. J Histochem Cytochem. 1977; 25(4):266-274.

[12] Sorimachi K, Yasumura Y, Kakuya T. Characterization of alkaline phosphatase in human urinary bladder carcinoma cell lines and enzyme regulation with prednisolone or sodium chloride. Jpn J Exp Med. 1985; 55(5):185-192.

[13] Vichai V, Kirtikara K. Sulforhodamine B colorimetric assay for cytotoxicity screening. Nature Protoc. 2006; 1(3):1112-1116.

[14] Thangaraju, M, Gopal E, Martin PM, Ananth S, Smith SB, et al. SLC5A8 triggers tumor cell apoptosis through pyruvate dependent inhibition of histone deacetylases. Cancer Res. 2006; 66(24):11560-11564.

[15] Siavoshian S, Blottiere HM, le Foll E, Kaeffer B, Cherbut C, et al. Comparison of the effect of different short chain fatty acids on the growth and differentiation of human colonic carcinoma cell lines in vitro. Cell Biol Int. 1997; 21(5):281-287.

[16] Brinske-Anderson MJ, Finley JW, Newman SM. The influence of culture time and passage number on the morphological and physiological development of Caco-2 cells. Proc Soc Exp Biol Med. 1997; 214(3):248257.

[17] Shin J, Carr A, Corner GA, Togel L, Davalos-Salas M, et al. The intestinal epithelial cell differentiation marker intestinal alkaline phosphatase (ALPi) is selectively induced by histone deacetylase inhibitors (HDACi) in colon cancer cells in a Kruppel-like factor 5 (KLF5)-dependent manner. J Biol Chem. 2015; 290(25):15392.

[18] Highman B, Frith CH, Littlefield NA. Alkaline phosphatase activity in hyperplastic and neoplastic urinary bladder epithelium of mice fed 2-acetylaminofluorene. J Natl Cancer Inst. 1975; 54(1):257-226.

[19] Sorimachi K. Induction of alkaline phosphatase activity by synergistic action of dibutyryl cyclic adenosine monophosphate, prednisolone, butyrate and sodium chloride in cultured cells. Cell Biochem Function. 1988; 6(1):25-29.

[20] Mariadason JM. HDACs and HDAC inhibitors in colon cancer. Epigenetics. 2001; 3(1):28-37.

[21] Huang $\mathrm{H}$, Liu N, Guo H, Liao S, Li X, et al. L-carnitine is an endogenous HDAC inhibitor selectively inhibiting cancer cell growth in vivo and in vitro. PLoS One. 2012; 7(11):e49062.

[22] Sharma U, Pal D, Prasad R. Alkaline phosphatase: An overview. Ind J Clin Biochem. 2014; 29(3):269-278.

[23] Al-Rashida M, Iqbal J. Inhibition of alkaline phosphatase: an emerging new drug target. Mini Rev Med Chem. 2015; 15(1):41-51.

[24] Damaskos C, Garmpis N, Valsami S, Kontos M, Spartalis E, et al. Histone deacetylase inhibitors: An attractive therapeutic strategy against breast cancer. Anticancer Res. 2017; 37(1):35-46.

[25] Lee KH, Song CG. Epigenetic regulation in bladder cancer: Development of new prognostic targets and therapeutic implications. Trans Cancer Res. 2017; 6(4):S677-S688. 